Svetlana Radovićc ${ }^{*}$, Jelena Sladojević Matić², Goran Opačić ${ }^{3}$ ${ }^{1}$ Elektromreža Srbije s.c.

${ }^{2}$ University Singidunum, Faculty of Media and Communications, Psychology department, Serbia ${ }^{3}$ University of Belgrade, Faculty of Philosophy, Serbia

\title{
Personality Traits Composition and Team Performance
}

DOI: 10.7595/management.fon.2020.0006

Abstract:

Research Question: This paper investigates a relationship between the composition of personality traits of team members and teamwork performance as well as team behavioural competences. Motivation: Our primary motivation was to link and integrate organizational psychology and the field of management science. The study builds on existing literature that highlights the influence of personality factors and their composition on group processes. As stated in the literature, personality traits determine individual behaviour in work environment and therefore influence group processes and group performance (Barric, Steward, Neubert, \& Mount, 1998). According to that, if we can determine such combinations of personality traits of team members that contribute to better or worse team performance, we can raise the team's efficiency to a maximum. Idea: The main idea of the research was to examine whether there is a combination of personality traits in a team that influences team performance. The importance of this topic is reflected in the increasing attention paid by organizations to working teams and their formation in order to increase productivity, so the adequate selection criteria of team members is of great importance. Data: The research was conducted in one Telecommunication Company. The final sample consisted of 20 teams formed by 87 subjects ( 42 male and 45 female). Every team consisted of $4-6$ members and the team supervisor. The teams were generally similar in terms of education. Tools: Personality traits of team members were measured with the instrument based on the Big five model. We used the average values of the team member's personality traits as the predictors, and team work performance as criteria. Beside descriptive statistics, we used correlation analysis and canonical and quasi canonical correlation analyses. Findings: Our findings mostly agree with similar studies in other countries - the average group result of Extraversion and Openness proved to be very important for the teamwork performance. The results strongly support the existence of one general personality factor which is connected to the teamwork performance. It therefore confirms a hypothesis that adequately formed teams contribute considerably to the success of an organization. Contribution: Perhaps the most important contribution of this paper lies in the fact that there are very few similar studies in our area and including our population, and the practical implications for management are huge.

Keywords: team composition, personality traits, team efficiency, team work performance, organizational psychology, management

JEL Classification: L20, M12, M59

\section{Introduction}

In order to understand how organizations function and successfully manage human potential, it is necessary to understand how people function within the groups or teams, as well as to understand the dynamics of relations and mutual influences that are significantly different from the individual behaviour. Managers steer the organizations by communicating to teams, not the individuals they consist of. Changes that they convey are the consequence of the synergy of people in groups/teams (Janicijevic, 2008), as well as of different roles they play in that constellation (Aritzeta, Swailes, \& Senior, 2007).

The research also shows that individual output varies in the presence of other persons (Jones, 2004). In the last 20 years teams have been more frequently mentioned in the management science and are differentiated with regard to working groups (Vujic, 2008), first of all by synergetic effects that are much bigger in 
teams in comparison with groups: the terms being used are team performances, shared leadership, complementary competences and collective responsibility for performances. Teams for solving problems, interfunctional teams, virtual and global teams are other examples increasingly being discussed (Leidner, Kayworth, \& Tavarez, 2001). Being very current and important within the management science this topic gives us a task to better understand the way that teams function successfully. One of the greatest challenges is to create a functional team since that affects almost every process of managing human resources - from selecting to achieving the strategic goals of the company.

\subsection{Theoretical background}

The tendency of a person to behave in a specific way is a function of their personality (Hogan, 1991). Metaanalyses consistently point to a relationship between certain personality traits of the Five factors model and different individual criteria of work performance (Barrick \& Mount, 1991; Hough, 1992). Personality traits determine the behaviour of the individual in work environment and therefore influence group processes and group performance (Barrick, Steward, Neubert, \& Mount, 1998).

Specific studies showed that the team productivity is characterised by the factors such as group coherence and cognitive problem solving (Kichuk \& Wiesner, 1997). Three main theoretical perspectives explain the nature of the influence of the personality to the team performance and group processes:

- Universal perspective, according to which certain personality traits predict successful teamwork - the personality shapes work performance through individual team members' behaviour and the group personality is observed through average score of the specific group's trait (Moreland \& Levine, 1984).

- Contiguous perspective, according to which personality has the influence on the team outcome through the interaction of the personality and situation (Magnusson \& Endler, 1977).

- Configurable perspective, according to which the combination of the personality traits within the group or members' mutual compatibility predict team success (Moynihan \& Randall, 2001).

The results of the studies that deal with the personality traits' influence on team behaviour and team performance have not so far offered a unique conclusion (Driskell, Hogan \& Salas, 1988).

One study (Bradley, Baur, Banford, \& Postlethwaite, 2013) showed that Agreeableness is one of the most important team performance predictors, while being a weak individual performance predictor. Apart from the group performance, agreeableness influences the group sustainability (Barrick et al., 1998), which is a consequence of the trait of "the cooperative" to care for the common good and other group members apart from care for themselves (Wagner, 1995).

Barrick and collaborators (1998) show that Consciousness operationalized through the average, but through the lowest group result, is a good predictor of team performance, while Neuman and Wright (1999) find considerable connection between consciousness expressed with the lowest group result and the supervisor's evaluation, even when they are expressed with objective signs such as quantity and quality of the work done.

Another research (Van Vianen, A. E., \& De Dreu, 2010) investigated, on the sample of 50 work teams, a relationship between the personalities, group cohesion and work performance of the team. They find that even a minimum level of Consciousness and Agreeableness contributes positively to both cohesion and team performance.

The research conducted by Barry and Steward (1997) proves that Extraversion is related to work performance and processes on both individual and group level. Another very important work by Barrick et al. (1998) show that teams with higher average extraversion level get higher scores of team performance by the supervisors. Also, Barry and Stewart (1997) show that groups with a higher proportion of extroverted members have a lower cohesiveness level and lower performance, which could be due to a high number of individuals who tend to be dominant.

Results of various research show that Neuroticism has a negative influence on the team work performance. Haythorn (1953) is among the first authors who demonstrated such a negative influence of this trait. Using the measure of the group average, he finds that the emotional stability is positively connected to the team performance. 
O'Neill and Allen (2011) found that Conscientiousness and its facets predicted team performance although Agreeableness, Extraversion and Neuroticism were not predictive of team performance, whereas Openness had a modest negative relation with team performance.

Neuman, Wagner and Chistiansen (1999) examined a connection between the team performance and two aspects of the team composition: the average level of a specific trait within the team and variability of the differences in the personality traits within the team. The results showed that the variability measure was connected to the team performance on Neuroticism and Extraversion, while for Consciousness, Agreeableness and Openness the team performance was connected to the average level of the traits.

In conclusion, as numerous research works indicate, all dimensions of the Five factor model are theoretically and empirically connected to team performance and a group composition influences its performance (Bradley, Klotz, Postlethwaite, \& Brown, 2013). Apart from the average level of a specific personality trait, some other composition aspects can influence the group performance such as minimum and maximum scores and a personality traits variance (Kramer, Bhave, \& Johnson, 2013).

\subsection{The problem and the aim of the research}

The main goal of this research was to examine connections between the composition of personality traits of team members, team performance and team behaviour competences.

\section{Method}

\subsection{Variables}

The independent variables in the research are: Five factors model personality traits operationalized through scores in Neo-Pi-R inventory (operationalized Disintegration and Amorality are also used in the research, but they are not relevant for the purposes of this paper).

Dependent variables in the research are:

Team performance (Performance methodology is such that every team gets 3 to 5 key goals for the next year with defined KPIs and defined valuation scale 1-5 (e.g., team KPI is the percentage of resolved malfunctions in the network where the grade 3 stands for $50-65 \%$ of resolved malfunctions and grade 4 stands for $65-75 \%$ of them).

Team behavioural competences (Performance methodology includes the goals and the evaluation of 4 team behavioural competences by a team leader on 1-5 scale where each grade is defined. The estimated competences are: Goals achievement: the employees are goal-oriented by actively directing themselves towards finalizing their tasks when achieving the specific goals of the company; Planning and organizing: employees plan and organise the work efficiently by approaching every work task with previously formed work plan; Team work: the employees show the ability of team work by treating one another like they treat their clients, they are attentive and helpful towards each other; Accepting the change: employees flexibly accept the changes by showing the openness to new and unpredicted circumstances).

\subsection{Research process and instruments}

The subjects filled up Neo-Pi-R inventory (Costa \& McCrae, 1985; translation and standardisation by Knezevic, Dzamonja-Ignjatovic, \& Djuric-Jocic, 2004) as operationalisation of personality traits of the Five factor model: Neuroticism (N), Extraversion (E), Agreeableness (A), Consciousness (C) and Openness (O). the instrument consists of 240 five-point Likert scale items. Team leaders filled up Questionnaire for an assessment of team behaviour competences. The researcher used the data about yearly performance of the team from an internal base.

\subsection{The Sample}

The research was conducted in the Telecommunication Company on 20 teams formed by 87 subject (42 male and 45 female). Every team consisted of 4-6 team members plus the team leader. The teams were 
generally similar as regards education (mostly telecommunication engineers). The team members work permanently together.

\section{The Research Results}

The results of the subjects concerning the personality traits are aggregated according to the teams. For every team, there is an average, standard deviation, a minimum and maximum for all personality traits. For each of those team parameters, there are correlations with the team work performance and behavioural competences.

Table 1: Correlation of team parameters and teamwork performance

\begin{tabular}{|c|c|c|c|c|c|}
\hline \multirow{2}{*}{$\begin{array}{c}\text { Big five } \\
\text { dimension }\end{array}$} & \multirow{2}{*}{$\begin{array}{l}\text { Team Work } \\
\text { Performance }\end{array}$} & \multicolumn{4}{|c|}{ Behavioural competences } \\
\hline & & $\begin{array}{c}\text { Goals } \\
\text { achievement }\end{array}$ & $\begin{array}{l}\text { Planning and } \\
\text { organizing }\end{array}$ & Team work & $\begin{array}{c}\text { Change } \\
\text { acceptance }\end{array}$ \\
\hline $\mathrm{N}$ _mean & -.07 & -.30 & .01 & .02 & -.14 \\
\hline E_mean & $.47^{*}$ & $.60^{\star \star}$ & .02 & .42 & .39 \\
\hline O_mean & .42 & $.60^{* *}$ & -.06 & .41 & .33 \\
\hline A_mean & .12 & $.46^{\star}$ & -.07 & .15 & -.03 \\
\hline C_mean & .14 & $.47^{\star}$ & -.13 & .01 & .17 \\
\hline N_sd & .12 & .32 & -.10 & .18 & -.01 \\
\hline E_sd & -.18 & -.25 & -.14 & -.29 & -.24 \\
\hline O_sd & -.22 & -.32 & -.12 & -.18 & -.26 \\
\hline A_sd & .12 & .11 & .01 & .22 & .08 \\
\hline C_sd & .15 & .07 & -.10 & .05 & -.01 \\
\hline N_min & -.12 & -.44 & .09 & -.16 & -.08 \\
\hline E_min & .40 & $.52^{\star}$ & .05 & .37 & .35 \\
\hline O_min & .38 & $.53^{*}$ & .07 & .26 & .34 \\
\hline A_min & .09 & .37 & -.01 & .09 & -.07 \\
\hline C_min & .04 & .29 & -.15 & .03 & .07 \\
\hline N_max & .09 & .02 & .03 & .10 & -.08 \\
\hline E_max & .19 & .27 & -.12 & .10 & .07 \\
\hline O_max & .28 & .35 & -.05 & .24 & .18 \\
\hline A_max & .20 & $.51^{*}$ & .07 & .25 & .05 \\
\hline C_max & .16 & .42 & -.24 & .10 & .12 \\
\hline
\end{tabular}

*. Correlations are significant on the level of 0.05 (2-tailed).

**. Correlations are significant on 0.05 level 0.01 level (2-tailed).

The results point out that the correlation between Extraversion expressed in the average of the team, the team work performance and the team's goal achievement is statistically significant. The average measure of Openness, Consciousness and Agreeableness correlates with goal achievement. Also, Openness expressed as the minimal result and Agreeableness expressed with the maximum result correlate to a significant extent with the same competence.

\subsection{Canonical and quasi canonical correlation analysis}

In order to prove a global covariance of the personality variables and teamwork performance, we performed a canonical analysis of the covariance using a SPSS macro programme (Knezevic \& Momirovic, 1996). The left group of variables consists of all the personality variables from the Neo Pi-R inventory. The right group of variables includes the variables that represent the Team Work Performance and the team's behaviour competences. 
Table 2: Coefficient, structure and cross- structure of the left group of variables

\begin{tabular}{|c|c|c|c|}
\hline Big five dimension & $\mathrm{W}$ & $\begin{array}{c}\mathrm{f}_{\mathrm{x}} \text { coefficient of the } \\
\text { structure }\end{array}$ & $\begin{array}{c}\mathrm{f}_{\mathrm{vx}} \text { coefficient of the } \\
\text { cross- structure }\end{array}$ \\
\hline $\mathrm{N}$ & -.19 & -.63 & -.21 \\
\hline $\mathrm{E}$ & .58 & .91 & .63 \\
\hline $\mathrm{O}$ & .56 & .91 & .61 \\
\hline $\mathrm{A}$ & .28 & .79 & .30 \\
\hline $\mathrm{C}$ & .30 & .89 & .33 \\
\hline Variance proportion & & .68 & .17 \\
\hline
\end{tabular}

Table 3: Coefficient, structure and cross- structure of the right group of variables

\begin{tabular}{|c|c|c|c|}
\hline $\mathbf{w}$ & $\begin{array}{c}\mathbf{f}_{\mathbf{x}} \text { coefficient of the } \\
\text { structure }\end{array}$ & $\begin{array}{c}\mathbf{f}_{\mathrm{vx}} \text { coefficient of the } \\
\text { cross- structure }\end{array}$ \\
\hline Team Performance & .43 & .84 & .33 \\
\hline Goals realisation & .73 & .89 & .58 \\
\hline $\begin{array}{c}\text { Planning and } \\
\text { organization }\end{array}$ & -.09 & .60 & $-0,69$ \\
\hline Team work & .33 & .73 & .26 \\
\hline Change acceptance & .36 & .69 & .29 \\
\hline Variance proportion & & .57 & .12 \\
\hline
\end{tabular}

The quasi-canonical correlation analysis showed a statistically significant quasi-canonical function ( $R o=$ $0.527, p<0.5)$. We may conclude that there is a connection between the team performance and the team members' personalities, i.e., the teams who have more stable and "healthier" members' personality structure function better and more efficiently. It seems that the general personality factor emerged as a latent structure that influences the team performance and efficiency. The highest correlations mentioned Personality G-factor has are with the traits of Extraversion and Openness. The personality traits G-factor explains $17 \%$ of the team work performance variance.

\section{Discussion}

The research results are mostly in concordance with the findings of different studies on the same topic that may be found in the literature.

The average value of Extroversion is in the considerable correlation between the team work performance and the team's goal achievement. A higher efficiency of the team with more extrovert members can be explained by a higher social cohesion of the team. The teams with the higher average of Openness dimension have better evaluations by the supervisors on Goals achievement. As this dimension supposes openness towards experience, the tendency towards learning and discovery, the high trait average is connected to functioning well in the situations that require flexibility and change acceptance. Similar results were obtained in the research by Neuman, Wagner and Christiansen (1999). A higher efficiency of the teams with more extroverted members, as well as members who are more opened to experiences can be explained by team's better social cohesion. The challenge of this finding lies in the possibility of composing the teams with dominantly introvert members with good qualities (e.g., programmers) - how to compose the teams that will achieve high standards. Extroversion is a predisposition, but in the field of development it is possible to develop team members towards active listening, social skills, team coaching etc. Developing teams this way in the long term creates an organization that is socially more responsive to the employees, dynamic, creative and productive. Due to high cohesiveness, members are more prone to help the team if they find themselves in the challenging situations and different surroundings (Liang, Shih \& Chiang, 2015). Similar results appeared in the research that was conducted by Van Vianen, \& De Dreu in 2010. The average and the maximum results on Agreeableness and the average on Consciousness on the team level is in the correlation with Goal achievement. Certain research works, as well as the one conducted by Bradley, Baur, Banford and Postlethwaite (2013), show that Agreeableness is one of the most important predictors of team performance, while it is a weak predictor of the individual performance. Neuman and Wright (1999) came to the conclusion that the team performance is in correlation with the minimum on the Consciousness dimension, 
which they explained as the potential conflicts which proceed from the team diversity. We can say that team members with higher Agreeableness have less need for a competitive attitude and achieve greater synergy in team performance. If Conscientiousness is added, we have a higher-level team performance.

The Neuroticism dimension did not show considerable correlations with the team work performance nor with any of the team behavioural competences. This fact is an important guideline for selection procedures because it shows us that neuroticism can be compensated by interaction in the group where a person feels safer and can share with the group, which is a confirmation of the group synergy.

The result of the quasi canonical analysis points to the existence of the general personality factor which influences team work performance. The teams with a more stable personality structure are more productive and they present better work habits. In the literature, Personality G-factor follows the logic of Spirman's general intelligence factor ( $\mathrm{g}$-factor) and has the highest correlations with Extraversion and Openness. As an interesting concept, the literature also gives a factor of team intelligence which influences team performance (Woolley, Chabris, Pentland, Hashmi \& Malone, 2010).

Following an analysis of 14 studies with the confirmed Five-factor personality structure, Digman (1997) emphasized two factors of the second order, named "personality meta-traits". The first factor includes emotional stability, kindness and consciousness, while the other includes Extraversion and Openness. According to Digman (1997), they are called the Alpha factor (stability of the emotional reaction, agreeableness and consistency in behaviour in terms of consciousness) and the Beta factor (openness towards experience and extraversion).

Becker (1999) calls these factors the behavioural control (alpha) and the mental health/ self-actualization (beta), while DeYoung (2006) calls them Stability (emotional stability, consciousness and kindness) and Plasticity (Extraversion and Openness). In the light of these results, as Extraversion and Openness show the highest correlations with the personality factor which influences the team performance, this result can be traced back to the beta factor, i.e., plasticity which has the highest influence on the efficiency of the teams, i.e., on their work performance.

The General personality factor or superdimension is at the top of the pyramid and it may be assumed that it has deep biological, neuropsychological and evolutionary roots. It consists of well- being, life content, general self-respect, social desirability, emotionality and motivation (Musek, 2011). Viswesvaran and Ones (2000) point to the general personality factor which has a higher importance than separate dimensions of The Big five in comparison with the work performance. John and Srivastava (1999) also talk about the integrative descriptive model which points to the existence of a general factor more than to individual dimensions of Big five.

The results of the meta-analytical study (van der Linden, Nijenhuis, \& Bakker, 2010) which examines the connection between the personality G-factor and teamwork performance point out that the General personality factor is a component connected to work performance, which is also in accordance with the results of this research.

As Repisti (2015) explains, the stability factor is related to activities performed devotedly (consciousness), to emotional reactions that are consistent (emotional stability) and cooperation with the others (agreeableness). In contrast with that, the plasticity is related to a tendency of an individual to achieve their rights and gain resources through social dominance, boldness, assertion and openness towards the surroundings (i.e., toward the others). Connections of the factors with work performance and work traits are very obvious from this definition, all in accordance with our findings. 


\section{Conclusion}

This research confirms the importance of team members' personality traits and their compatibility. The frame and the structure of personality influences the achievements of the team. We conclude that efficient teams are the future of organizational behaviour and that a goal of organizational psychology is to explore possibilities of team development through training, systemic corporative coaching (Hawkins, 2006), solution-focused organizational coaching (Dierlof, 2014). Also the focus should be shifted from individual development measures to an organization as a whole and its teams. This should be supported by a better development of work place consulting (Carroll, 1996) that steers interventions towards the development of the organization - systemic approach. Our findings point to existence of a personality factor that influences the performance. The importance of this research is based on the assumption that the adequately formed teams contribute considerably to the success of the organisation.

Perhaps the largest limitation in our research was the sample size of 87 employees organized in 20 teams. To obtain results with higher significance levels, a larger sample should be considered and that could be a subject of another possible research in the future.

Further research also needs to better articulate the operationalization of the evaluation process of the team behavioural competences with the purpose of decreasing subjectivity of the supervisor. Another constraint is the fact that the teams are at the same time the working groups which exist in the structure of the organization and work together during a longer period of time, as well as the fact that the teams are specific educational structures (primarily technical).

An advantage of this research lies in the fact that it was performed in a real company on teams that work side by side for a longer period of time, in contrast with artificially formed teams that perform certain tasks in controlled conditions, which was the case with a certain number of research works that we quoted in this paper. This very fact opens the possibility of further longitudinal research on the same sample on which some corrective measures can be applied and the effects followed.

Further research should focus on the type of activity the teams perform in the context of separating manipulative and creative tasks, considering that the sort of tasks can affect the relationship between the composition of personality traits and the performance (Lugo, Zapata-Ramos, \& Puig, 2017).

\section{REFERENCES}

[1] Aritzeta, A., Swailes,S., \& Senior,B. (2007). Belbin's Team Role Model: Development, Validity and Applications for Team Building. Journal of Management Studies, 44(1), 96-118, DOI: 10.1111/j.14676486.2007.00666.x

[2] Barrick, M. R., \& Mount, M. K. (1991): The Big Five personality dimensions and job performance: A meta-analysis; Personnel Psychology, 44, 1-26 DOI: 10.1111/j.1744-6570.1991.tb00688.

[3] Barrick,M., Stewart,G.R., Neubert, M.J., \& Mount, M.K.(1998). Relating Member Abilityand Personality to Work-Team Processe and Team Effectiveness, Journal of Applied Psychology, 83(3), 377-391, DOI:10.1037/0021-9010.83.3.377

[4] Barry, B., \& Stewart, G. L. (1997). Composition, process, and performance in self-managed groups: The role of personality. Journal of Applied Psychology, 82, 62-78 DOI:10.1037/0021-9010.82.1.62

[5] Becker, P. (1999). Beyond the Big Five. Personality and Individual Differences, 26, 511-530. DOI: 10.1016/S0191-8869(98)00168-8

[6] Bradley, B. H., Klotz, A. C., Postlethwaite, B. E., \& Brown, K. G. (2013). Ready to rumble: How team personality composition and task conflict interact to improve performance; Journal of Applied Psychology, 98, 385-392, DOI: 10.1037/a0029845

[7] Bradley,B.H., Baur, J.E., Banford, C.G., \& Postlethwaite, B.E (2013). Team Players and Collective Performance: How Agreeableness Affects Team Performance Over Time. Small Group Research, 44(6), 680-711, DOI: 10.1177/1046496413507609

[8] Carroll, M. (1996). Workpalce Counselling: A Systematic Approach to Employee Care. SAGE Publications, London

[9] Costa, P.T. \& McCrae, R., R. (1985).The NEO Personality Inventory Manual. Odessa, FL: Psychological Assessment Resources

[10] DeYoung, C. G. (2006). Higher-order factors of the Big Five in a multiinformant sample. Journal of Personality and Social Psychology, 91, 1138-1151. DOI: 10.1037/0022-3514.91.6.1138

[11] Dierlof, K. (2014). Solution - Focused Team Coaching. Solutions Academy, Verlag 
[12] Digman, J. (1997). Higher-order factors of the Big Five. Journal of Personality and Social Psychology, 73, 1246-1256, DOI: 10.1037//0022-3514.73.6.1246

[13] Driskell, J.E., Hogan,R.,\& Salas,E. (1988). Personality and group performance. Review of Personality and Social Psychology, 14, 91-112. DOI: 10.21236/ada187539

[14] Haythorn, W. (1953). The influence of individual members on the characteristics of small groups. The Journal of Abnormal and Social Psychology, 48(2), 276-284. DOI: 10.1037/h0058211

[15] Hogan, R.T. (1991). Personality and personality assessment in: M.D, Hough, L.M. Handbook of Industrial and Organizational psychology,3. Consulting Psychologist Press, Palo Alto, CA, 873-919, DOI: 10.1037/10434-013

[16] Hough, L.M. (1992): The 'Big Five' Personality Variables-Construct Confusion: Description Versus Prediction; Human Performance, 5, 139-155 DOI:10.1080/08959285.1992.9667929

[17] Janicijevic, N. (2008). Organizaciono ponašanje, [Organizational behaviour]. Beograd: Data status

[18] John, O. P., \& Srivastava, S. (1999). The big five trait taxonomy: History, measurement, and theoretical perspectives". Handbook of personality: Theory and research, 2(1999), 102-138.

[19] Jones, R. (2004). The science and meaning of the self, The Journal of analyitical psychology, 49(2), 217-233 DOI: 10.1111/j.1465-5922.2004.00454.x

[20] Kichuk, S., \& Wiesner, W. (1997). The Big Five Personality Factors and Team Performance: Implications for Selecting Successful Product Design Teams. Journal of Engineering and Technology Management, 14, 195-221, DOI: 10.1016/s0923-4748(97)00010-6

[21] Knezevic, G. \& Momirovic, K. (1996). Algoritam i program za analizu relacija kanoničke korelacijske analize i kanoničke analize kovarijansi, In: Kostic, P. (Ed.). Problemi merenja u psihologiji 2, IKSI, Centar za primenjenu psihologiju, Beograd.

[22] Knezevic, G., Dzamonja-Ignjatovic,T., \& Djuric-Jocic,D. (2004). Petofaktorski model ličnosti, [Big five personality model], CPP, Beograd

[23] Kramer, A., Bhave, PD., \& Johnson, D.T., (2013). Personality and Team Performance: The Importance of Personality Composition and Work Tasks. Personality and Individual Differences, 58, 132-137, DOI: 10.1016/j.paid.2013.10.019

[24] Leidner, D., Kayworth,T.R., \& Mora-Tavares, M.(2001). Leadership effectiveness in global virtual teams. Journal of management informational system, 18(3), 7-40 DOI:10.1080/07421222.2002.11045697

[25] Liang, H. Shih, A.H., \& Chiang,Y.H. (2014). Team diversity and team helping behavior: The mediating roles of team cooperation and team cohesion. European Management Journal, 33(1), DOI: 10.1016/j.emj.2014.07.002

[26] Lugo, J.E., Zapata-Ramos, M.L., \& Puig, C.P. (2017). Exploration of Entrepreneurial Student Teams Performance and Student Team Members' Personality via the Big Five Test. Conference paper presented at ASME 2017 International Design Engineering Technical Conferences and Computers and Information in Engineering Conference, DOI: 10.1115/DETC2017-67922

[27] Magnusson, D., \& Endler, S.N (1977). Toward an interactional psychology of personality. Psychological Bulletin, 83(5), 956 to 974, DOI:10.1037//0033-2909.83.5.956

[28] Moreland, R. L., \& Levine, J. M. (1984). Role Transitions in Small Groups. Springer Boston MA, 181-195 DOI: $10.1007 / 978-1-4613-2697-7 \_13$

[29] Moynihan, L.M., \& Randall S.P. (2001). A contigent Configuration Approach to Understandinf the Role of Personality in Organizational Groups. Research in Organizational behaviour 23, 327-78 DOI: 10.1016/s0191-3085(01)23008-1

[30] Musek, J. (2011). Generalni faktor osebnosti in nova strukturna teorija osebnosti. Anthropos, 1-2, 1134

[31] Neuman, G. A., \& Wright, J. (1999).Team effectiveness: Beyond skills and cognitive ability. Journal of Applied Psychology, 84(3), 376-389. DOI:10.1037/0021-9010.84.3.376

[32] Neuman, G.A., Wagner, S.H., \& Cristiansen, N.D (1999). The relationship between work-team personality Composition and the Job Performance Teams. Group\&Organization management, 24(1), 28-45, DOI: $10.1177 / 1059601199241003$

[33] O'Neill, T.A., \& Allen, N. J. (2011). Personality and the prediction of team performance. European Journal of Personality, 25(1), 31-42, DOI: 10.1002/per.769

[34] Repisti, S. (2015). Psihologija ličnosti: Teorija i empirija [Personality Psychology:Theory and Research], drugo prošireno izdanje, 221-228

[35] Van der Linden, D., te Nijenhuis, J., \& Bakker, A. B. (2010). The General Factor of Personality: A metaanalysis of Big Five intercorrelations and a criterion-related validity study. Journal of Research in Personality,44 (3), 315-327, DOI: 10.1016/j.jrp.2010.03.003

[36] Van Vianen, A. E., \& De Dreu, C. K. (2010). Personality in teams - Its relationship to social cohesion, task cohesion and team performance. European journal of work and organizational psychology, 10(2), 97120, DOI: $10.1080 / 13594320143000573$ 
[37] Viswesvaran, C., \& Ones, D. S., (2000). Measurement error in "big five factors" personality assessment: Reliability generalization across studies and measures. Educational and Psychological Measurement, 60(2), pp. 224-235, DOI: 10.1177/00131640021970475

[38] Vujic, D. (2008). Menadžment ljudskih resursa i kvalitet. Beograd: Centar za primenjenu psihologiju.

[39] Wagner, J. A. (1995). Studies of individualism-collectivism: Effects on cooperation in groups. Academy of Management Journal, 38, 152-172. DOI: 10.5465/256731

[40] Woolley, AW., Chabris, CF., Pentland, A., Hashmi,N, \& Malone, TW. (2010). Evidence for a Collective Intelligence Factor in the Performance of Human Groups. Science, 330, 686-688, DOI: 10.1126/science. 1193147

Received: 2019-07-27

Revision requested: 2019-10-02

Revised: 2020-02-07 (2 revisions)

Accepted: 2020-04-10

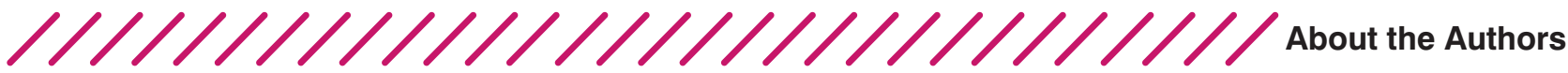

\section{Svetlana Radović \\ Elektromreža Srbije s.c. e-mail: svetlana.radovic@ems.rs}

Svetlana Radovic, MA, Director of Human Potential Development department in Elektromreža Srbije, with more than 13 years of experience in the field of Human Resources in HR development. Faculty of Media and Communication, Department of

Psychology, Visiting Lecturer in HR Consulting and Organizational Psychology.

$$
\begin{array}{r}
\text { Jelena Sladojević Matić } \\
\text { University Singidunum, Faculty of Media and Communications, Serbia } \\
\text { e-mail: jelenasladojevicmatic@yahoo.com }
\end{array}
$$

Jelena Sladojević Matic, PhD, Faculty of Media and Communication, Department of

Psychology. Assistant Professor and Lecturer in Organizational Psychology and Occupational Psychology, HR Consulting. Rich academic and practical experience in the field of organizational consulting.
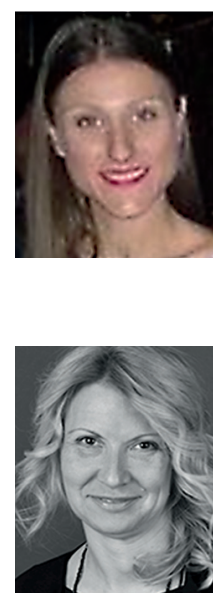

Goran Opačić

University of Belgrade, Faculty of Philosophy, Serbia e-mail: opacicg@f.bg.ac.rs

Goran Opačić, PhD, Faculty of Philosophy, Department of Psychology, Associate Professor and Lecturer in Psychometry, Psychology of Individual Differences and Application of Psychological Testing. Rich academic and practical experience in the field of HR consulting. 